\title{
Biosimilar Medicines in the Iranian Market: a Way to More Affordable Medicines
}

\author{
NAZILA YOUSEFI, RAZIEH AHMADI, H. TAYEBA, S. TAHERI, F. MAHBOUDI ${ }^{1}$ AND F. PEIRAVIAN ${ }^{1 *}$ \\ Department of Pharmaco-economics and Pharma Management, School of Pharmacy, Shahid Beheshti University of Medical \\ Sciences, ${ }^{1}$ Biotechnology Research Center, Pasteur Institute of Iran, Tehran, Iran
}

\section{Yousefi et al.: Biosimilar Medicines in the Iranian Market}

\begin{abstract}
The rise of biosimilar provides an opportunity for healthcare systems worldwide to reduce costs and ensure affordability as well as accessibility of these pivotal products. This is particularly the case in developing countries with restricted budgets to guarantee the availability of safe and cost-effective drugs. Accordingly, this paper aims to study Iranian pharmaceutical industry to show the development of the biosimilar sector, which has emerged in the wake of an intense global interest in the production and marketing of biosimilar. This paper adopted a descriptive cross-sectional method to investigate the Iranian pharmaceutical industry by focusing on biosimilar products over a fifteen-year period (2002-2016). Results obtained showed an upward trend in the domestic production of biosimilars, which has helped secure the first place for the country in the Middle East. In addition, Iran has laid down strict regulatory guidelines for the approval of locally produced biosimilar. The findings also highlight the significant savings generated for the healthcare system thanks to the manufacturing of non-innovator products. These results suggested that observing global regulatory guidelines and providing safe and cost-effective biosimilars are imperative for health care systems in all countries interested in this promising market.
\end{abstract}

Key words: Biosimilar pharmaceuticals, affordability, market research, Iran pharmaceutical market, biological medicines

The biopharmaceutical market has expanded dramatically in the past two decades. The substantial clinical utility and commercial success of these products have convinced large pharmaceutical companies to engage in the research and development ( $R$ and $D$ ) of biological medicines ${ }^{[1]}$. The biopharmaceutical medicine market has a promising future such that it is projected its value will have risen up to 52 billion dollars just in Europe and the US market by $2020^{[2]}$.

In recent years, besides insulin and diagnostic products, many other biotech products in the class of cancer treatment, immune system and AIDS have come onto the market and it is expected that this market will grow further with drugs for cell therapy and gene therapy, with vaccines for cancer prevention joining them in the next few years ${ }^{[3]}$. In 2014, biologic medicines accounted for $23 \%$ of the global pharmaceutical market and in 2016, 20 out of the top 100 best-selling drugs were biologics. In addition, over $32 \%$ of medicines in the pipeline are biologics ${ }^{[4]}$.

Although these products are highly effective and lifealtering therapies, they have a high unit cost and are

*Address for correspondence

E-mail: peiravianfarzad@gmail.com

May-June 2020 often used for chronic conditions that require on-going treatment. Accordingly, the production of biosimilars has been exploited as the most effective strategy for health care systems to curb inflation in pharmaceutical prices and ensure better accessibility ${ }^{[5]}$. As a result, by using biosimilars, the economic savings have been so considerable for both developed and developing countries that they managed to account for $40 \%$ of the biomedicine market in $2015^{[4,6]}$. In the next few years with the patent expiration of original products, the biosimilar market will experience a boom more than ever and pharmaceutical manufactures and regulatory authorities will turn their attention more to this market ${ }^{[7]}$.

The rise of the biosimilar market has also provided an unparalleled opportunity for firms in some developing countries to engage in the production of these products.

This is an open access article distributed under the terms of the Creative Commons Attribution-NonCommercial-ShareAlike 3.0 License, which allows others to remix, tweak, and build upon the work non-commercially, as long as the author is credited and the new creations are licensed under the identical terms 
In the same line, in an attempt to curb costs and ensure more affordability and accessibility of these pivotal products, the Iranian government has devised some policies to support biosimilar manufacturers. Over the years, although the Iranian pharmaceutical industry has developed a knowledge base embedded in organic and synthetic chemistry, its technological capacity is often limited to the formulation of generic medicines ${ }^{[2,8]}$. Not only have biotech companies improved the level of pharmaceutical knowledge in the Iranian pharmaceutical industry, but also turned Iran into a biomedicine market leader in the Middle East and North Africa; in fact, in terms of market capacity, in Asia, Iran is second only to India ${ }^{[9]}$. In addition, some Iranian leading biosimilar companies have entered into some other markets like Turkey and Russia.

Analysis of the market revealed that the pharmaceutical market was worth over 4.2 billion US dollars in 2016, $70 \%$ of which was accounted for imported medicines. Biological medicines accounted for $60 \%$ of the value of these imported drugs, but for vaccines as they are directly purchased and provided by the government and their value is not reflected in Iran's pharmaceutical market. Likewise, the last official published data by Iranian Food and Drug Organization in 2016, confirm that 18 biosimilar products have been launched by domestic firms and 15 are in the $\mathrm{R}$ and $\mathrm{D}$ pipeline. Accordingly, the investigation of the field analysis showed that the number of domestically produced biosimilars increased to 24 in 2018 .

The above-mentioned upward trend in the domestic production of biosimilar medicines has been the motivation to investigate the current situation of the Iranian pharmaceutical industry with respect to biosimilar medicines. This paper tries to describe the Iranian biosimilar market and its brilliant outcomes for the Iranian healthcare system. It is hoped that the results of this study generate baseline data for late comer economies to increase their awareness of the biosimilar industry.

\section{MATERIALS AND METHODS}

This is a descriptive cross-sectional study, which examines the Iranian pharmaceutical market, focusing on biosimilar development over a 15-y period from 2001 to 2016. The data were extracted from various sources such as published reports on the history of biologic industry in Iran, official data and documents released by the ministry of health, as well as the pharmaceutical statistical data sheets published by Iranian Food and
Drug Organization. In addition, this study highlights trends in Iran's biosimilar market in terms of value and volume.

\section{The biosimilar industry in Iran:}

The opportunity for marketing of biosimilars in Iran is significantly expanding as approximately $7 \%$ of pharmaceutical companies in Iran are actively involved in the production and development of these products. Iran has a long history in the production of biological medicines. Razi and Pasture institutes, two state-owned companies, have been active in vaccine production for $90 \mathrm{y}$. In the last few decades, the first technological collaboration in new recombinant products has been between Pasture institute and the international center for biotechnology and genetic engineering of Cuba in building the production facility for recombinant hepatitis vaccine and three other recombinant pharmaceutical proteins, i.e. erythropoietin, interferon alpha, and streptokinase. The production and R and D of high technology products is hailed as a significant breakthrough in the Iranian pharmaceutical industry. Presently, there are 7 pharmaceutical companies, which exclusively produce biosimilars and have been able to extend their production capability to upstream stages of production. In addition, some conventional pharmaceutical companies have taken up biosimilar production in order to expand their generic portfolio. Table 1 shows the number of biosimilars that are produced from upstream stages and the intensity of competition. Apart from Razi and Pasteur, which are well-established pharmaceutical companies with a proven track record, the average age of other biotech companies are 12.8 y (6-90 y). Furthermore, apart from Razi Vaccine and Serum Institute with 133 researchers and 1250 staff on the payroll ${ }^{[9]}$ other biotech companies on average have 500 staff on the payroll within a 55-500 member range and, consequently, can be classified as small or middle-sized companies. Although Razi Vaccine and Serum Institute boasts over 2.5 billion doses of 55 varieties of animal and human biotech products and diagnostic antigens, the number of biotech drugs produced by other biotech drug producers ranges from 1 to 11 , averaging out at 4.5 items. With investment in technological capabilities, the number of new-to-market biosimilars had increased over the years as shown in (fig. 1). In addition to market attraction, the industrial policies adopted by the Iranian government played a critical role in the growth of the biosimilar sector. The industry developed largely thanks to the adoption of policies based on financial 


\begin{tabular}{lc}
\hline Company Name & Products \\
\hline Aryogen & Etanercept, Factor VII, Trastuzumab, Rituximab, Bevacizumab \\
Cinnagen & INF $\beta$-1a, Rituximab, Pegfilgrastim, \\
& Etanercept, Teriparatide, Follitropin alfa, \\
Faravardehaye notarkib & Adalimumab, Erythropoietin \\
Pooyesh daoo & INF gamma \\
INF alfa-2b, Filgrastim, \\
Saman Darou \\
Zist Darou Danesh \\
Aryatinagen & Erythropoietin recombinant, \\
& Peg INF alfa, Erythropoietin \\
\hline
\end{tabular}

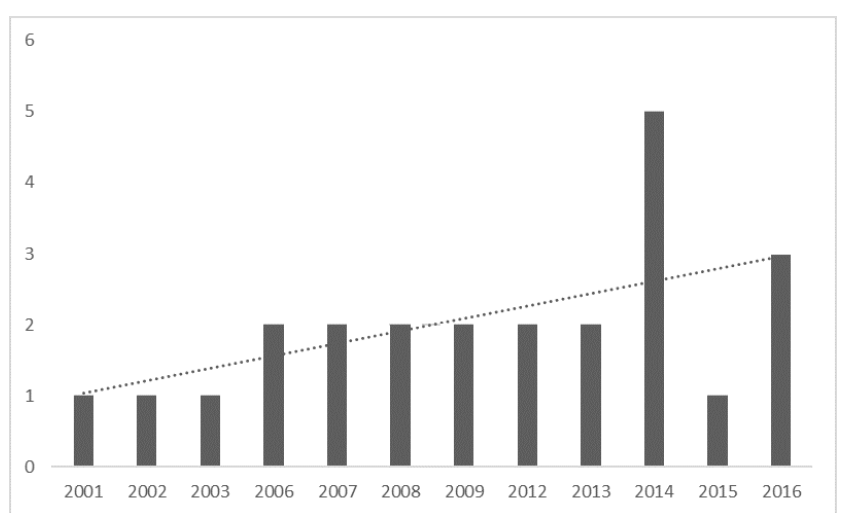

Fig. 1: New biosimilar molecules launched (2001-2016) The number of new biosimilar molecules launched onto the Iranian market in a 15-year period (2001-2016)

facilities, registration fast track, and import restriction which, to a large extent, focused on indigenization. As a result, some firms started research and development to build a wide range of production capabilities to penetrate into the local market. So, the market growth in 2001 to 2016 for domestically produced biosimilar medicines was $90.8 \%$ (in terms of value), which shows a dramatic increase in comparison to the $27.4 \%$ growth for local generic drugs in the same period. As shown in (fig. 2), the market for domestic biosimilar medicines had a dramatic growth both in volume and value. This market growth in the biosimilar section is significantly higher than the total pharmaceutical market growth in Iran. As shown in Table 2, in 3 periods of 5, 10 and $15 \mathrm{y}$, the market growth of domestic biosimilar medicines was higher than that of the overall biosimilar section, overall domestic section, and general pharmaceutical market in Iran.

\section{Biosimilars and access:}

In terms of molecular diagnosis, drug delivery systems, biotech knowledge can go a long way toward ensuring health for people, in particular in developing countries. One of its remarkable achievements has been the production of recombinant protein drugs and

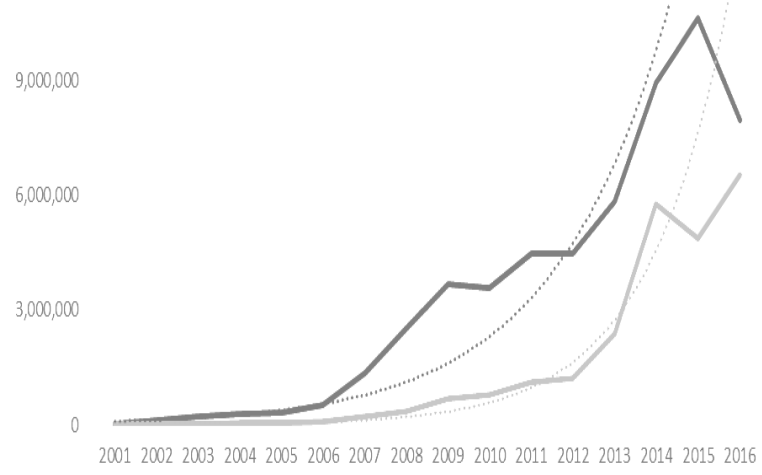

Fig. 2: Market trend of domestically produced biosimilar drugs The upward trend in the market for domestically produced biosimilar drugs, (-) in volume, $(-)$ in value (million Rial)

vaccines ${ }^{[10]}$. However, despite its great benefits, only a few countries can exploit this technology; the US is the market leader in the field of biotech products and has produced many recombinant drugs, vaccines, and coagulation factors exploiting this technology.

Prior to applying for a patent for human genome mapping by the National Institute of Health in 2001, which led to some amendments in patent laws, 5000 patents about DNA had been registered in the Patent Office. This patenting adversely affected scientists' and academia's research activities regarding patented drugs and processes. Although in the following years some changes were made to the patenting laws, the tragedy of anticommons, a legacy of the patenting system before any changes were made to the laws, precluded the possibility of doing many researches in this field. In addition to this, today, biotech drug producers are faced with many challenges resulting from the patenting of microorganisms and the patenting of production processes.

As huge financial resources are allocated for the research and development of these products, their intellectual property rights, which patenting laws try to protect, 
TABLE 2: THE AVERAGE MARKET GROWTH IN DIFFERENT SECTIONS (2001-2016)

\begin{tabular}{lccc}
\hline & 5 y & 10 y & 15 y \\
\hline Domestic biosimilars & $53.4 \%$ & $61.4 \%$ & $90.8 \%$ \\
Total market & $34.8 \%$ & $36.3 \%$ & $46.9 \%$ \\
Total locally manufactured & $34.4 \%$ & $28.4 \%$ & $27.4 \%$ \\
pharmaceutical market & & & \\
Total Iranian pharmaceutical market & $31.4 \%$ & $27.5 \%$ & $28.2 \%$ \\
\hline
\end{tabular}

prove a huge challenge and despite the importance of encouraging innovation and protecting the investments made in this field, many experts point to the adverse effects patenting laws can have on people's health, specifically in low- and middle-income countries.

Once new drug patents expire, rivals try to carve out a niche in the market and the resulting competitive atmosphere causes a rapid decline in their prices. For example, the biosimilar filgrastim, which was introduced onto the American market in 2015 by Sandoz in the wake of the expiration of the neupogen patent, sold $16 \%$ cheaper. It explains why parent companies spare no effort to prevent the introduction of biosimilar drugs and extend the term of the patent of their products. There are various perspectives about the effect of patent protection on innovation. Since accessing innovator companies' propriety data is not possible under patent protection, the developer of biosimilars has to retrieve the reference product, purify it, and reverse engineer a process to produce a copy, which requires the establishment from scratch of a new manufacturing process. Although patent protection can encourage innovation, it can also hamper the development and promotion of science by preventing scientists from researching on patented products. Besides, it can lead to the underutilization of patented drugs on the market.

Leading companies often try to extend the patent period of their products by changing their formulation and production methods and by applying minor improvement long after their patents have been expired. Despite all these measures, some countries like India kept the opportunity for their pharmaceutical companies to diversify into this field by wisely modifying patent laws after joining the World Trade Organization ${ }^{[11]}$. On the other hand, some other countries like Iran have been able to domestically produce and use these patented products due to delay in joining the World Trade Organization. As Iran is yet to join the World Trade Organization and, consequently, is not legally bound to respect intellectual property rights as stipulated in international treaties, the production of patented drugs even prior to their patent expiration is possible ${ }^{[12]}$.

Apart from patent laws, the production of recombinant drugs in developing countries has to overcome other obstacles like heavy investments for upstream and downstream production as well as the necessity to acquire, high-level knowledge about cellular biology, genetic engineering, biochemistry, process engineering, formulation, purification, fermentation. In addition, the absence of regulatory standard guidelines in these countries has hampered the introduction of these drugs onto the market because developing countries generally wait for the development of these regulatory guidelines by developed countries that are often tardy in drawing up these guidelines for reasons like political-economic considerations or the technical complications involved in the production of these drugs ${ }^{[11]}$. Accordingly, the strong regulatory body in Iran whose biological department was approved as a fully functional national regulatory body in 2009, helps local biosimilar manufacturers make their products easily accessible. The last version of the Iranian registration regulation for biosimilar products, originally published $20 \mathrm{y}$ ago and revised several times since then. According to Iran registration regulatory for biosimilar products, and according to Doha Ministerial Conference in November 2001, protection of patents does not and should not prevent countries from taking measures to protect public health. So, one of the features of the regulatory environment in Iran for domestic manufacturers is limited international patent protection, allowing pharmaceutical firms to produce patented as well as offpatent products. The corollary of this policy is reducing the time lag between the patent expiration of original drugs and the introduction of biosimilar products onto the local market, as shown in Table 3. As the access to patent products in the local market is facilitated, many patients use the advantage of affordable products and a great life year achieved in our middle-income country.

\section{RESULTS AND DISCUSSION}

Although biologics have offered patients and health systems invaluable treatment alternatives, they are unaffordable in many low-middle income countries because they work out much more expensive than their chemical counterparts so much that on average the cost of treatment with biotech drugs is 22 times more ${ }^{[13]}$. Therefore, in the biotech drug market, the production of generic biosimilar drugs has been exploited as the most effective strategy to curb inflation in drug prices 
TABLE 3: TIME LAG BETWEEN PATENT EXPIRATION OF THE ORIGINAL BRAND AND THE LAUNCH OF THE BIOSIMILAR MOLECULE ONTO THE DOMESTIC MARKET

\begin{tabular}{lccc}
\hline Product name & Patent expiration year & $\begin{array}{c}\text { Launched onto the } \\
\text { Iranian market }\end{array}$ & $\begin{array}{c}\text { Number of years prior } \\
\text { to patent expiration }\end{array}$ \\
\hline Adalilumab $40 \mathrm{mg} / 0.8 \mathrm{ml}$ inj. & 2016 & 2016 & 0 \\
Erythropoietin $10000 \mathrm{U} / \mathrm{ml}$ & 2014 & 2008 & 6 \\
Erythropoietin $4000 \mathrm{IU} / 0.5 \mathrm{ml}$ & 2014 & 2009 & 5 \\
Erythropoietin $4000 \mathrm{U} / \mathrm{ml}$ & 2014 & 2007 & 7 \\
Erythropoietinrecombinant $2000 \mathrm{IU} / \mathrm{ml}$ & 2014 & 2006 & 8 \\
Etanercept $25 \mathrm{mg} / 0.5 \mathrm{ml}$ & 2012 & 2013 & -1 \\
Etanercept $50 \mathrm{mg} / \mathrm{ml}$ & 2012 & 2014 & -2 \\
Factor VII $1.2 \mathrm{mg}$ & 2011 & 2014 & -3 \\
Factor VIII $(\mathrm{recombinant)}$ & 2012 & 2015 & -3 \\
Filgrastim $300 \mu \mathrm{g} / 0.5 \mathrm{ml}$ & 2013 & 2003 & 10 \\
Follitropin $\alpha 75 \mathrm{IU}$ & 2017 & 2014 & 3 \\
INF alfa-2b $3 \mathrm{mIU}$ & 2002 & 2000 & 2 \\
INF $\beta$-1a $30 \mu \mathrm{g}$ & 2013 & 2006 & 7 \\
INF $\beta$-1a $44 \mu \mathrm{g} / 0.5 \mathrm{ml}$ & 2013 & 2009 & 4 \\
INF $\beta$-1b $9.6 \mathrm{million} \mathrm{U}$ & 2017 & 2013 & 4 \\
INF $\gamma 100 \mu \mathrm{g}$ & 2008 & 2008 & 0 \\
Peg INF $\alpha 180 \mu \mathrm{g} / 0.5 \mathrm{ml}$ & 2007 & 10 \\
Pegfilgrastim $6 \mathrm{mg} / 0.6 \mathrm{ml}$ & 2017 & 2014 & 1 \\
Rituximab $100 \mathrm{mg} / 10 \mathrm{ml}$ & 2015 & 2011 & 2 \\
Rituximab $500 \mathrm{mg} / 50 \mathrm{ml}$ & 2013 & 2011 & 2 \\
Teriparatide $750 \mu \mathrm{g} / 3 \mathrm{ml}$ & 2013 & 2014 & 3 \\
Trastuzumab $150 \mathrm{mg}$ & 2017 & 2016 & -1 \\
\hline
\end{tabular}

and ensure better accessibility. Producing generic biomedicines benefits not only patients due to better accessibility but also manufacturers in terms of financial profits accruing to them. Although the price of a bio-generic medicine is $20-30 \%$ lower than that of innovator product, even at this price range, some generic drugs prove more profitable than patented drugs because the producers do not have to invest heavily in $\mathrm{R}$ and $\mathrm{D}$ or in marketing. Moreover, like generic drugs, biosimilar medicines have helped healthcare systems to save huge sums ${ }^{[14]}$.

As a case in point, it is estimated that these drugs, in particular monoclonal antibodies, will have helped save 11.8 to 33.4 billion Euros in Europe from 2007 to 2020. The money saved only from erythropoietin has amounted to 9.4 to 11.2 billion Euros in this time period $^{[15]}$. Although the complications involved in the production process and the control of biotech drugs and the lack of transparency in their registration have posed some problems for the introduction of biosimilar drugs onto the market, their economic profits have been so considerable that they managed to account for $40 \%$ of the biotech drug market in $2015^{[4]}$. In addition to increasing demand in new treatments by biotech medicines, their knowledge-based nature, which means that huge resources are diverted to research and development and marketing, helps them bring about more economic profits.

In Iran, domestically produced biosimilar medicines have had a positive effect on patients' out-of-pocket expenses and helped the healthcare system to decrease the costs. In recent years, domestically produced drugs have replaced their imported counterparts, making up about half the drug market in both value and volume, as shown in fig. 3. Figs. 4A and B demonstrate the market share of different treatment classes in terms of value and volume, which also shows which kind of patients have taken more advantage of domestic biosimilar medicines. It is worth noting that antineoplastic agents constituted about $54 \%$ of the market in terms of value in 2016 and domestic biosimilar medicines made treatments more affordable in these life-threatening diseases. Similarly, fig. 4B shows the great volume share of immunomodulator medicines that can be used in cancer patients. The next group of patients who have saved the most by using these domestic products are patients who need antihemorrhagic agents, gonadotropins and other ovulation stimulants, immunosuppressant, and immunomodulating agents. In the pharmaceutical industry, the government has taken forward the import limitation strategy through the substitution of biosimilars for originator biologics. 


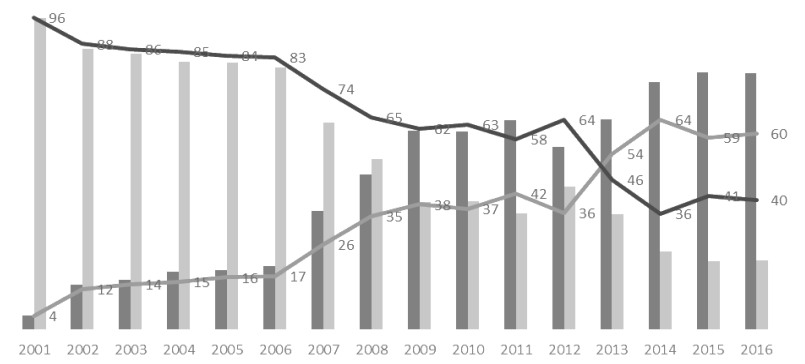

Fig. 3: Percent market share of domestic and imported biosimilars (2001-2016)

Percent market share of domestic biosimilars and imported innovator brands in Iran (2001-2016). (-) Domestic product share (volume), $(-)$ imported product share (volume), $(-)$ domestic product share (value), (-) imported product share (value)

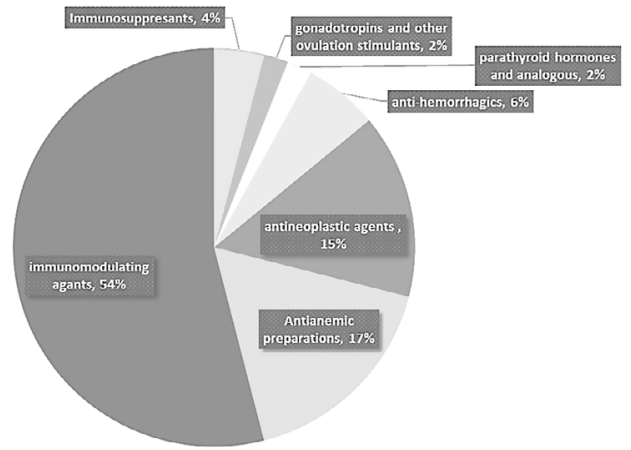

A

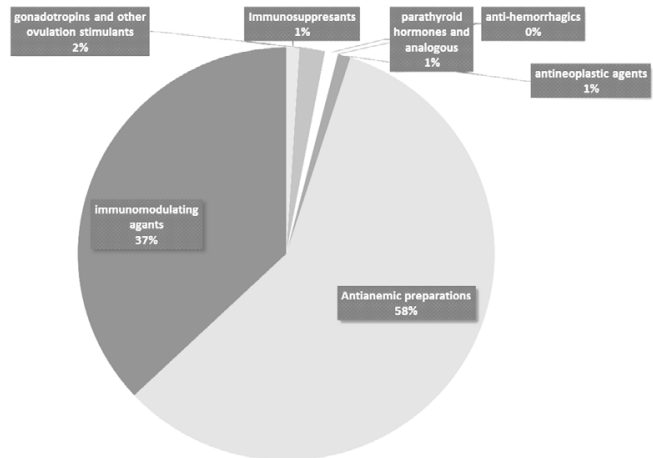

B

Fig. 4: Share of different treatment classes in the domestic biosimilar market in 2016

Market share by A. value and B. volume of different treatment classes in domestically produced biosimilars in 2016

Under strong policy of import substitution, selling of imported biologics would be prevented after domestic production. Therefore, to calculate the saving generated by domestically produced biosimilars in the last year of this study, we have worked out the difference between the average price of imported drugs, mostly branded medicines, and the average price of the domestically produced biosimilar. Then, as shown in Table 4, the sum total was calculated by considering the whole consumption of each medicine in the mentioned year.
Since all data such as biologic drug prices and market volume were extracted from the last officially published statistics by Iran's FDA in 2016, The exchange rate used for this estimation was the mean exchange rate over the year 2016 (USD 1= IRR 31 364). The total amount of saving in healthcare budget in 2016, the last year of data availability, was estimated at about USD 348066164 . However, a survey on the price of biologics in European countries illustrated that the prices in Iran is lower than global prices. It could be due to several reasons including the lower income in Iran than Europe and thusly the lower willingness to pay threshold in cost-effectiveness studies, which leads the prices to be lower. In addition, it might be due to the bargaining power of Iran's Ministry of Health because of the low price of internally produced biosimilars. Indeed, assuming the global price for biologics to be sold in Iran, the total amount of saving in healthcare budget in 2017 would be estimated up to 940 million USD. Furthermore, if this saved amount were considered for several years since they entered into the local market, the total saving would be dramatically higher.

Biosimilars could have a major impact on the affordability of biopharmaceuticals in all markets, particularly in low-resource countries. The annual saving of these products, which was around USD 350 million in 2016, is significant in Iran's health system. Similarly, it has been reported that newly established biosimilar medicines have already generated around 1.4 billion Euros saving per year for European healthcare systems. Obviously, this saving might be used for the next generation of original medicines ${ }^{[16]}$ and to improve patients' access to innovative medicines. Accordingly, it is imperative that late-coming economies be able to provide safe and cost-effective drugs for its huge noninsured and poor population. In India, over 50 different brands of biosimilar products have been approved for more than 20 different biopharmaceutical companies and some of these molecules have completed a decade of market presence with several thousand doses already administered $^{[7]}$. The South Korean government is actively promoting the biosimilar industry in order to make South Korea a market leader in this field. The government is providing both financial and institutional support and is aiming to command a $22 \%$ share of the global market by $2020^{[15,17]}$.

In Latin America, many governments have developed regulatory pathways for biosimilars to increase access while enacting sufficient quality standards to ensure safety and efficacy. Argentina, as a major producer of 
TABLE 4: THE SAVING GENERATED BY DOMESTICALLY PRODUCED BIOSIMILARS

\begin{tabular}{|c|c|c|c|c|c|}
\hline Biosimilar product & $\begin{array}{l}\text { Average price } \\
\text { of domestic } \\
\text { biosimilars }(\$)\end{array}$ & $\begin{array}{l}\text { Average price } \\
\text { of Imported } \\
\text { products }(\$)\end{array}$ & Difference & $\begin{array}{c}\text { The volume } \\
\text { of biosimilar } \\
\text { product in the } \\
\text { market }\end{array}$ & $\begin{array}{c}\text { Cost saving } \\
\text { (\$) }\end{array}$ \\
\hline Adalimumab 40 mg/0.8 ml inj. & 240.4 & 297.1 & 56.7 & 14510 & 823,225 \\
\hline Erythropoietin $10000 \mathrm{IU}$ & 14.7 & 37.9 & 23.3 & 407046 & $9,479,588$ \\
\hline Erythropoietin $2000 \mathrm{U} / \mathrm{ml}$ syringe & 14.9 & 12.5 & -2.36 & 105000 & $-247,902$ \\
\hline $\begin{array}{l}\text { Erythropoietin recombinant hu } 2000 \\
\text { IU/vial }\end{array}$ & 3 & 4 & 1 & 590950 & 595,282 \\
\hline $\begin{array}{l}\text { Erythropoietin recombinant hu } 4000 \\
\text { IU/vial }\end{array}$ & 5.9 & 9 & 3.2 & 2912970 & $9,284,020$ \\
\hline Etanercept 25 mg inj. & 62.1 & 117 & 54.8 & 177550 & $9,736,575$ \\
\hline Etanercept 50 mg inj. & 125 & 194.8 & 69.8 & 78090 & $5,452,302$ \\
\hline $\begin{array}{l}\text { Antihemophilic factor VIII } \\
\text { (recombinant) } 500 \mathrm{U} \text { vial }\end{array}$ & 3 & 91.8 & 88.7 & 12390 & $1,099,264$ \\
\hline Filgrastim (GCSF) $300 \mu \mathrm{g} / 0.5 \mathrm{ml}$ inj. & 19.4 & 31.8 & 12.4 & 453558 & $5,605,230$ \\
\hline Pegfilgrastim $6 \mathrm{mg} / 0.6 \mathrm{ml}$ injection & 164.1 & 785.7 & 621.6 & 21490 & $13,358,480$ \\
\hline $\begin{array}{l}\text { Pegfilgrastim injection, parenteral } 10 \\
\mathrm{mg} / 1 \mathrm{ml}\end{array}$ & 140 & 670.2 & 530.2 & 99250 & $52,625,107$ \\
\hline Interferon $\alpha-2 b 3$ mega vial & 2.4 & 28.4 & 26.1 & 54180 & $1,413,349$ \\
\hline Interferon $\alpha$-2b 5 mega vial & 3.5 & 42.6 & 39 & 34010 & $1,327,693$ \\
\hline Interferon $\beta$-1a $30 \mu \mathrm{g}$ vial & 43.1 & 160.6 & 117.6 & 804460 & $94,588,583$ \\
\hline Interferon $\beta$-1a $44 \mu \mathrm{g} / 0.5 \mathrm{ml}$ syringe & 31.4 & 83.7 & 52.4 & 707500 & $37,069,390$ \\
\hline Interferon $\beta$-1b 8 mlU vial & 21 & 42.7 & 21.6 & 204500 & $4,420,801$ \\
\hline $\begin{array}{l}\text { Interferon } \beta-1 \mathrm{a} \text { injection parenteral } \\
1.2 \mathrm{e}+007 \mathrm{IU} / 0.5 \mathrm{ml}\end{array}$ & 47.8 & 64 & 16.2 & 542750 & $8,773,506$ \\
\hline Interferon $\beta$-1b 9.6 million $U$ inj. & 19.9 & 38.9 & 19 & 217140 & $4,123,045$ \\
\hline Interferon $\gamma 100 \mu \mathrm{g}$ & 17.2 & 51.7 & 34.4 & 29000 & 998,055 \\
\hline $\begin{array}{l}\text { Peginterferon } \alpha-2 a 180 \mu \mathrm{g} / 0.5 \mathrm{ml} \\
\text { syringe }\end{array}$ & 19.9 & 148.3 & 128.4 & 217140 & $27,877,888$ \\
\hline $\begin{array}{l}\text { Peginterferone } \alpha 180 \mu \mathrm{g} / 0.5 \\
\mathrm{ml}+\text { ribavirin } 200 \mathrm{mg}\end{array}$ & 53.2 & 152.9 & 99.7 & 20140 & $2,007,200$ \\
\hline Rituximab 100 mg/10 ml vial & 141.2 & 284.8 & 143.6 & 56170 & $8,064,994$ \\
\hline Rituximab 500 mg/50 ml vial & 672 & $1,308.20$ & 636.2 & 28380 & $18,056,238$ \\
\hline Teriparatide $750 \mu \mathrm{g} / 3 \mathrm{ml}$ vial & 170.7 & 574.5 & 403.8 & 58740 & $23,719,211$ \\
\hline Trastuzumab 150 mg vial & 441.5 & 536.7 & 95.3 & 30220 & $2,878,679$ \\
\hline Trastuzumab 440 mg vial & $1,149.70$ & $1,396.90$ & 247.2 & 19970 & $4,936,360$ \\
\hline Total Saving & & & & & $348,066,164$ \\
\hline
\end{tabular}

biosimilar in the Latin American region, has developed supportive policies which allow the substitution of biosimilars for branded biologics ${ }^{[6]}$. Technological capabilities of Iran's biosimilar industry have turned Iran into a biomedicine market leader in the Middle East and North Africa; in fact, in terms of market capacity, in Asia, Iran is second only to India ${ }^{[9]}$. Analysis of the Iranian market shows that some private companies like the Cinnagen group, which are involved in the research and development of biosimilars, have moved toward export markets such as the Middle East, Russia and South Africa. In addition, they have succeeded in licensing out technology to some countries like Turkey, strongly suggesting the attainment of a certain level of advanced biosimilar capabilities. Availability of biosimilar products offers major price advantages and cost saving for the country as price of non-innovator products are about 30 to 40 percent lower than that of the originator products. Assuming that evolving regulatory pathways can succeed in ensuring requisite comparability of the safety and efficacy of molecules of varying degrees of complexity, the discounts afforded to these biosimilar therapies should offer interesting cost-effective alternatives for payers and consumers to consider in order to address their health care needs.

\section{REFERENCES}

1. McCamish M, Woollett G. Worldwide experience with biosimilar development. MAbs 2011;3(2):209-17.

2. Cheraghali AM. Iran pharmaceutical market. Iranian J Pharm Res 2010;16(1):1-7.

3. Ecker DM, Jones S. D, Levine HL. The therapeutic monoclonal antibody market. MAbs 2015;7(1):9-14. 
4. Simoens S. Biosimilar medicines and cost-effectiveness. Clinicoecon Outcomes Res 2011;3:29.

5. Horikawa H, Tsubouchi M, Kawakami, K. Industry views of biosimilar development in Japan. Health Policy 2009;91:18994.

6. Azevedo VF, Sandorff E, Siemak B, Halbert R J. Potential regulatory and commercial environment for biosimilars in Latin America. Value Health Reg 2012;1(2):228-34.

7. Malhotra H. Biosimilars and non-innovator biotherapeutics in India: An overview of the current situation. Biologicals 2011;39(5):321-24.

8. Yousefi N, Mehralian G, Peiravian F, Jahangiri S, Ahmadi R. Physicians' perceptions of generic medicine in Iran. Drug Ther Perspect 2011;31(7):244-50.

9. Mahboudi F, Hamedifar H, Aghajani H. Medical biotechnology trends and achievements in Iran. Avicenna J Med Biotechnol 2012;4(4):200.

10. Acharya T, Daar AS, Singer PA. Biotechnology and the UN's millennium development goals. Nat Biotechnol 2003;21(12):1434.
11. Genazzani AA, Biggio G, Caputi AP, Del Tacca, M Drago, F Fantozzi, R, et al. Biosimilar Drugs. BioDrugs 2007;21(6):35156.

12. Cheraghali AM. Iran Pharmaceutical Market. Iran J Pharm Res 2006;1:1-7.

13. Simoens S. Health economics of market access for biopharmaceuticals and biosimilars. J Med Economics 2009; 12(3):211-18.

14. Hackbarth GM, Crosson F J, Miller M E. Report of the Congress: improving incentives in the Medicare program. Medicare Payment Advisory Commission 2009. Availabel from: http:/www.medpac.gov/docs/default-source/reports/ Jun09_EntireReport.pdf.

15. Haustein R, de Millas C, Höer A, Häussler B. Saving money in the European healthcare systems with biosimilars. GaBI J 2012;1(3-4):120-26.

16. Cornes P. The economic pressures for biosimilar drug use in cancer medicine. Target Oncol 2017;1:57-67.

17. Huzair F, Dinar K. Biosimilars and the long game. Trends Biotechnol 2015;33(5):250-52. 